\title{
Phase Change of Si-Al Alloy Prepared by Carbon Reduction Coal Fly Ash
}

\author{
Zhiling Bai 1,a, Bingke Qin 1,2,b, Minglei Lian ${ }^{1, c}$, Yingju Miao ${ }^{1,3, d}$
}

${ }^{1}$ School of Chemistry and Materials Engineering, Liupanshui Normal University, Liupanshui,China

${ }^{2}$ College of Materials and Metallurgy, Guizhou University, Guiyang, China

${ }^{3}$ School of Chemical Engineering,Kunming University of Science and Technology, Kunming,China

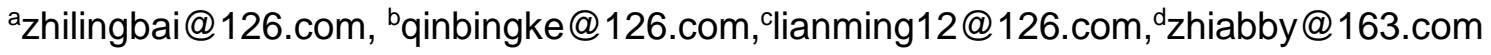

Keywords: Si-Al alloy; HSC chemistry; coal fly ash; reduction;carbon

Abstract.The thermodynamic data of atmospheric pressure were calculated by using HSC chemistry 6.0 software, and the thermodynamic conditions were discussed theoretically.It indicated that the simultaneous reduction of alumina and silicon oxide by carbon at high temperature was beneficial to reduce $\mathrm{SiC}$ and $\mathrm{Al}_{4} \mathrm{C}_{3}$ in the products. It is feasible to prepare $\mathrm{Si}-\mathrm{Al}$ alloy by carbon reduction coal fly ash from thermodynamic analysis. The thermodynamic equilibrium components of carbon reduction coal fly ash were simulated by using Equilibrium Composition module, and it was considered that most of the reactions occurred during the reaction were the coupling of two or more reactions, rather than one by one.The preparation of $\mathrm{Si}-\mathrm{Al}$ alloy by carbon reduction coal fly ash is viable. In order to improve the yield of silicon and aluminum, the method of heating rapidly can be used to avoid the formation of carbide, thereby reducing the content of $\mathrm{Al}_{2} \mathrm{O}$ and $\mathrm{SiO}$ in the equilibrium composition.

\section{Introduction}

With the development of power industry, the output of coal fly ash is increasing year by year. If the output of coal fly ash is not handled properly, it will have negative effects on air, water quality, soil and human health.Coal fly ash contains a large number of useful resources, and its main components are alumina and silicon oxide,it's a secondary resource with development and utilization value[1]. Silicon-aluminum alloy has excellent mechanical, thermal and corrosion resistance, it has been widely used in various industrial sectors, it can also be used as deoxidizer in steel-making and magnesium reduction agent[2,3].Coal fly ash is a ideal raw material for carbon thermal reduction method to extract silicon-aluminum alloy.It can expand the applications of coal fly ash and extend the coal industry chain,coal and electricity industry sustainable development and reduce the environmental pollution of coal fly ash. It is beneficial to high value-added utilization of coal fly ash.Therefore, it is significant to study the preparation of Si-Al alloy by carbothermal reduction using coal fly ash as raw material.

\section{Research methods}

The reaction equation of HSC Chemistry 6.0 thermodynamics software is used to analysis the thermodynamic conditions for the preparation of silicon-aluminium alloy with carbon reduction coal fly ash. The change of Gibbs free energy of each reaction with temperature are calculated and analyzed theoretically.Equilibrium component are calculated by equilibrium compositions module of HSC Chemistry 6.0. The relationship between temperature and system equilibrium components, the effect of temperature on the reduction process can be obtained.It is useful to further explore the mechanism of carbon reduction coal fly ash to improve the comprehensive utilization rate of coal fly ash.It also has certain guiding significance to the smelting process of carbon thermal reduction coal fly ash. 


\section{Results and discussion}

\section{Thermodynamic analysis of carbon reduction coal fly ash.}

The main components of coal fly ash are alumina and silicon oxide, and carbothermal reduction of coal fly ash is used to prepare silicon-aluminum alloy.It is mainly carbon reduction alumina and silicon oxide, so as to extract silicon and aluminum.According to the literature[4], in the Al-Si-O-C system, there may be some substances such as: $\mathrm{Al}_{2} \mathrm{O}_{3}, \mathrm{SiO}_{2}, \mathrm{Al}_{4} \mathrm{C}_{3}, \mathrm{SiC}, \mathrm{Al}_{4} \mathrm{O}_{4} \mathrm{C}, \mathrm{C}, \mathrm{Al}_{2} \mathrm{CO}, \mathrm{Al}, \mathrm{Si}$, $\mathrm{Al}_{2} \mathrm{O}(\mathrm{g}), \mathrm{SiO}(\mathrm{g}), \mathrm{CO}(\mathrm{g})$ and so on. The reaction process of preparing silicon-aluminum alloy by carbon thermal method is very complicated, involving many chemical reactions, considering only the main chemical reactions. Therefore, thermodynamic calculations mainly involve the chemical reactions of alumina and silicon oxide. The thermodynamic data of atmospheric pressure (100kPa) are calculated by using HSC chemistry 6.0 software, and the thermodynamic conditions are discussed theoretically.The main chemical reactions that may occur during the preparation of Si-Al alloy by carbon reduction coal fly ash are shown in table 1 .

Table 1 The main chemical reactions that may occur during the preparation of Si-Al alloy by carbon reduction coal fly ash

\begin{tabular}{clcc}
\hline No. & $\mathrm{Reaction}$ equation & $\Delta \mathrm{G}^{0}=\mathrm{A}+\mathrm{BT} / \mathrm{kJ} \cdot \mathrm{mol}^{-1}$ & $\begin{array}{c}\text { The starting } \\
\text { temperature } / \mathrm{K}\end{array}$ \\
\hline$(1)$ & $\mathrm{Al}_{2} \mathrm{O}_{3}+3 \mathrm{C}=2 \mathrm{Al}+3 \mathrm{CO}(\mathrm{g})$ & $320.8-0.139 \mathrm{~T}$ & 2308 \\
$(2)$ & $\mathrm{Al}_{2} \mathrm{O}_{3}+3 \mathrm{C}=\mathrm{Al}_{2} \mathrm{CO}+2 \mathrm{CO}(\mathrm{g})$ & $182.8-0.082 \mathrm{~T}$ & 2229 \\
$(3)$ & $2 \mathrm{Al}_{2} \mathrm{O}_{3}+9 \mathrm{C}=\mathrm{Al}_{4} \mathrm{C}_{3}+6 \mathrm{CO}(\mathrm{g})$ & $579.8-0.255 \mathrm{~T}$ & 2273 \\
$(4)$ & $2 \mathrm{Al}_{2} \mathrm{O}_{3}+3 \mathrm{C}=\mathrm{Al}_{4} \mathrm{O}_{4} \mathrm{C}+2 \mathrm{CO}(\mathrm{g})$ & $194.9-0.092 \mathrm{~T}$ & 2118 \\
$(5)$ & $2 \mathrm{Al}_{2} \mathrm{CO}+3 \mathrm{C}=\mathrm{Al}_{4} \mathrm{C}_{3}+2 \mathrm{CO}(\mathrm{g})$ & $216.6-0.094 \mathrm{~T}$ & 2304 \\
$(6)$ & $\mathrm{Al}_{2} \mathrm{O}_{3}+\mathrm{Al}_{4} \mathrm{C}_{3}=6 \mathrm{Al}+3 \mathrm{CO}(\mathrm{g})$ & $381.9-0.161 \mathrm{~T}$ & 2372 \\
$(7)$ & $\mathrm{Al}_{4} \mathrm{O}_{4} \mathrm{C}+6 \mathrm{C}=\mathrm{Al}{ }_{4} \mathrm{C}_{3}+4 \mathrm{CO}(\mathrm{g})$ & $388.1-0.167 \mathrm{~T}$ & 2324 \\
$(8)$ & $\left.\mathrm{SiO}_{\mathrm{g}}\right)+2 \mathrm{C}=\mathrm{SiC}+\mathrm{CO}(\mathrm{g})$ & ------------ & ----- \\
$(9)$ & $\mathrm{SiO}_{2}+2 \mathrm{C}=\mathrm{Si}+2 \mathrm{CO}(\mathrm{g})$ & $162.9-0.084 \mathrm{~T}$ & 1939 \\
$(10)$ & $\mathrm{SiO}_{2}+2 \mathrm{SiC}=3 \mathrm{Si}+2 \mathrm{CO}(\mathrm{g})$ & $203.0-0.095 \mathrm{~T}$ & 2154 \\
$(11)$ & $\mathrm{SiO}_{2}+3 \mathrm{C}=\mathrm{SiC}+2 \mathrm{CO}(\mathrm{g})$ & $143.3-0.079 \mathrm{~T}$ & 1814 \\
$(12)$ & $\mathrm{SiO}_{2}+\mathrm{C}=\mathrm{SiO}(\mathrm{g})+\mathrm{CO}(\mathrm{g})$ & $162.1-0.079 \mathrm{~T}$ & 2052 \\
$(13)$ & $\mathrm{SiO}_{2}+2 \mathrm{Si}=2 \mathrm{SiO}(\mathrm{g})$ & $162.1-0.075 \mathrm{~T}$ & 2150 \\
$(14)$ & $3 \mathrm{SiO}_{2}+2 \mathrm{Al} \mathrm{C}_{3}=8 \mathrm{Al}+3 \mathrm{Si}+6 \mathrm{CO}(\mathrm{g})$ & $611.7-0.297 \mathrm{~T}$ & 2059 \\
$(15)$ & $3 \mathrm{Al}_{2} \mathrm{O}_{3} \cdot 2 \mathrm{SiO}+6 \mathrm{C}=\mathrm{Al} \mathrm{O}_{3}+2 \mathrm{SiC}+4 \mathrm{CO}(\mathrm{g})$ & $1220.0-0.658 \mathrm{~T}$ & 1854 \\
$(16)$ & $3 \mathrm{SiC}_{2} \mathrm{Al} \mathrm{O}_{3}=2 \mathrm{Al}+3 \mathrm{Si}+3 \mathrm{CO}(\mathrm{g})$ & $1554.9-0.630 \mathrm{~T}$ & 2468 \\
$(17)$ & $2 \mathrm{Al}_{2} \mathrm{CO}+\mathrm{SiO}{ }_{2}=2 \mathrm{Al}{ }_{2} \mathrm{O}(\mathrm{g})+\mathrm{Si}+2 \mathrm{CO}(\mathrm{g})$ & $1649.0-0.722 \mathrm{~T}$ & 2284 \\
$(18)$ & $2 \mathrm{Al}_{2} \mathrm{O}(\mathrm{g})+\mathrm{C}=2 \mathrm{Al}+\mathrm{CO}(\mathrm{g})$ & $80.9-0.046 \mathrm{~T}$ & 1758 \\
$(19)$ & $3 \mathrm{Al}_{2} \mathrm{O}(\mathrm{g})+\mathrm{Al}_{4} \mathrm{C}_{3}=10 \mathrm{Al}+3 \mathrm{CO}(\mathrm{g})$ & $507.8-0.234 \mathrm{~T}$ & 2170 \\
$(20)$ & $\left.\mathrm{SiO}_{\mathrm{O}} \mathrm{g}\right)+\mathrm{C}=\mathrm{Si}+\mathrm{CO}(\mathrm{g})$ & -------------- & ----- \\
\hline
\end{tabular}

It can be seen from table 1 that mullite reacts with carbon to produce alumina at $1854 \mathrm{~K}$, and that silicon dioxide is easier to react with carbon than aluminum oxide. Silicon dioxide and carbon begin to produce silicon carbide at $1814 \mathrm{~K}$, generate $\mathrm{Si}$ at $1939 \mathrm{~K}$. At higher temperature $2052 \mathrm{~K}$, there is $\mathrm{SiO}$ generation. $\mathrm{SiO}$ can react with carbon to form silicon and silicon carbide in the temperature range from $500 \mathrm{~K}$ to $2500 \mathrm{~K}$. At $2154 \mathrm{~K}$, silicon dioxide reacts with silicon carbide to form silicon, and silicon dioxide and silicon react at $2150 \mathrm{~K}$ to produce SiO. The initial temperature of aluminum oxide reacts with carbon to produce aluminum is $2308 \mathrm{~K}$, while the initial temperatures for $\mathrm{Al}_{4} \mathrm{C}_{3}$, $\mathrm{Al}_{4} \mathrm{O}_{4} \mathrm{C}$ and $\mathrm{Al}_{2} \mathrm{CO}$ are $2273 \mathrm{~K}, 2118 \mathrm{~K}$, and $2229 \mathrm{~K}$. The starting temperature for $\mathrm{Al}_{4} \mathrm{C}_{3}, \mathrm{Al}_{4} \mathrm{O}_{4} \mathrm{C}$ and $\mathrm{Al}_{2} \mathrm{CO}$ are lower than that of aluminum generation temperature, so carbide formation in alumina is inevitable in carbon reduction aluminum oxide. $\mathrm{SiO}_{2}$ reacts with $\mathrm{Al}_{4} \mathrm{C}_{3}$ to form aluminum and silicon at $2059 \mathrm{~K}$. At $2284 \mathrm{~K}, \mathrm{SiO}_{2}$ reacts with $\mathrm{Al}_{2} \mathrm{CO}$ to form low valent oxide of aluminium alumina $\mathrm{Al}_{2} \mathrm{O}$, with silicon generation. $\mathrm{Al}_{2} \mathrm{O}$ reacts with carbon to form aluminum at $1758 \mathrm{~K}$. At $2170 \mathrm{~K}, \mathrm{Al}_{2} \mathrm{O}$ can 
react with $\mathrm{Al}_{4} \mathrm{C}_{3}$ to generate aluminum. SiC reacts with $\mathrm{Al}_{2} \mathrm{O}_{3}$ to form aluminum and silicon at $2468 \mathrm{~K}$. At $2304 \mathrm{~K}, \mathrm{Al}_{2} \mathrm{CO}$ reacts with carbon to form $\mathrm{Al}_{4} \mathrm{C}_{3}$. At $2372 \mathrm{~K}, \mathrm{Al}_{2} \mathrm{O}_{3}$ reacts with $\mathrm{Al}_{4} \mathrm{C}_{3}$ to generate aluminum. At $2324 \mathrm{~K}, \mathrm{Al}_{4} \mathrm{O}_{4} \mathrm{C}$ reacts with carbon to form $\mathrm{Al}_{4} \mathrm{C}_{3}$. It is feasible to prepare $\mathrm{Si}-\mathrm{Al}$ alloy by carbon reduction coal fly ash from thermodynamic analysis. In order to increase the yield of $\mathrm{Si}$ and $\mathrm{Al}$, the temperature can be rapidly raised and the formation of carbides can be reduced.The simultaneous reduction of alumina and silicon oxide by carbon at high temperature is beneficial to reduce $\mathrm{SiC}$ and $\mathrm{Al}_{4} \mathrm{C}_{3}$ in the products.Christoph Kemper[5] predicted the thermodynamic model of carbon reduction reaction of alumina and silicon oxide, it indicated that could effectively reduce the carbide formation in aluminum with the existence of silicon oxide, and reduce the volatilization loss of the low valent oxide of aluminium.

\section{Effect of temperature to equilibrium composition.}

Simulation of chemical reaction process of $\mathrm{Si}-\mathrm{Al}$ alloy prepared by carbon reduction coal fly ash using Equilibrium composition module of HSC Chemistry 6.0 chemical thermodynamics software.

It needs to establish a thermodynamic system:the system is a closed system, constant pressure system is $100 \mathrm{kPa}$, the initial composition are coal fly ash and carbon. The mass ratio of initial component are $\mathrm{Al}_{2} \mathrm{O}_{3}: \mathrm{SiO}_{2}: \mathrm{C}=12: 23: 14$.Effect of temperature to equilibrium composition are shown in Fig.1.

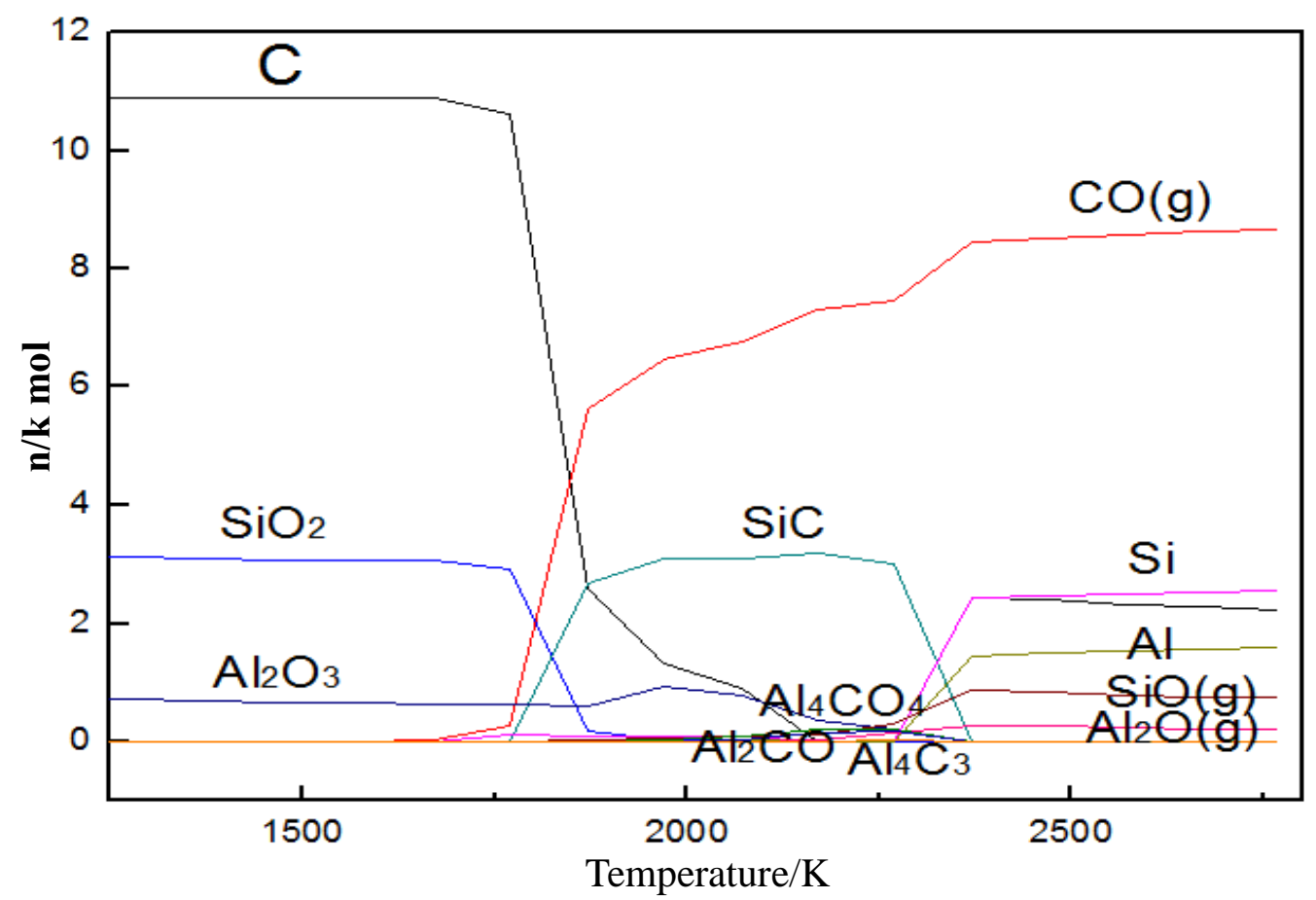

Fig. 1 Effect of temperature to equilibrium composition

The equilibrium composition and content of the system at different temperature are shown in Fig. 1. With the increase of temperature, the equilibrium composition and content of the system change constantly, and the process of preparing silicon-aluminum alloy by carbon reduction coal fly ash is not a single reaction.It can be seen from Fig. 1, with the increase of temperature, the content of carbon and silicon oxide are decreased gradually and new components of carbon monoxide and silicon carbide are appeared.The number of new components show the increasing tendency, while the content of alumina in the process remain unchanged, indicating that at first carbon reacts with silicon oxide to form silicon carbide and carbon monoxide. When the temperature exceeds $1800 \mathrm{~K}$, the content of carbon monoxide and silicon carbide is increased rapidly, and the content of silicon oxide and carbon are decreased sharply.Within the temperature range of $1800 \mathrm{~K}-1900 \mathrm{~K}$, the reaction between carbon and silicon oxide to produce silicon carbide and carbon monoxide is the most violent. When the temperature is more than $1900 \mathrm{~K}$, the content of silicon carbide is increased slowly, after reaching a certain extent the content of silicon carbide is almost unchanged. At about $1900 \mathrm{~K}$, the content of silicon oxide is dropped to zero, which indicates that silicon oxide has been 
completely reacted to form silicon carbide. At $2000 \mathrm{~K}$, the content of alumina is began to decrease gradually. With the increase of temperature, the content of carbon decreases sharply, and $\mathrm{Al}_{4} \mathrm{O}_{4} \mathrm{C}$, $\mathrm{Al}_{2} \mathrm{CO}$ and $\mathrm{Al}_{4} \mathrm{C}_{3}$ are formed in the products, which indicates that carbon reacts with alumina to form $\mathrm{Al}_{4} \mathrm{O}_{4} \mathrm{C}, \mathrm{Al}_{2} \mathrm{CO}$ and $\mathrm{Al}_{4} \mathrm{C}_{3}$. At $2300 \mathrm{~K}, \mathrm{Si}, \mathrm{Al}, \mathrm{SiO}$ and $\mathrm{Al}_{2} \mathrm{O}$ are generated, and with the increase of temperature the content of $\mathrm{Al}_{4} \mathrm{O}_{4} \mathrm{C}, \mathrm{Al}_{2} \mathrm{CO}, \mathrm{C}, \mathrm{SiC}$ and $\mathrm{Al}_{4} \mathrm{C}_{3}$ are decreased gradually. When the temperature reaches $2375 \mathrm{~K}$, the content of $\mathrm{Si}, \mathrm{Al}, \mathrm{SiO}$ and $\mathrm{Al}_{2} \mathrm{O}$ reach the maximum value and tend to be stable, and the content of $\mathrm{Al}_{4} \mathrm{O}_{4} \mathrm{C}, \mathrm{Al}_{2} \mathrm{CO}, \mathrm{SiC}$ and $\mathrm{Al}_{4} \mathrm{C}_{3}$ are decreased to zero, indicating that $\mathrm{Al}_{4} \mathrm{O}_{4} \mathrm{C}, \mathrm{Al}_{2} \mathrm{CO}, \mathrm{SiC}$ and $\mathrm{Al}_{4} \mathrm{C}_{3}$ have been completely reacted. In this process, complex chemical reactions have been taken place, $\mathrm{Al}_{4} \mathrm{O}_{4} \mathrm{C}, \mathrm{Al}_{2} \mathrm{CO}$ and $\mathrm{Al}_{4} \mathrm{C}_{3}$ have been converted into $\mathrm{Al}$ and $\mathrm{Al}_{2} \mathrm{O}$, and $\mathrm{SiC}, \mathrm{SiO}_{2}$ have been converted into $\mathrm{Si}$ and $\mathrm{SiO}$. From the relationship between thermodynamic temperature and the equilibrium composition of the system, it can be concluded that the preparation of Si-Al alloy by carbon reduction coal fly ash is feasible. In order to improve the yield of silicon and aluminum, the method of rapid heating can be used to avoid the formation of carbide, thereby reducing the content of $\mathrm{Al}_{2} \mathrm{O}$ and $\mathrm{SiO}$ in the equilibrium composition.

\section{Conclusions}

The thermodynamic data of atmospheric pressure were calculated by using HSC chemistry 6.0 software, and the thermodynamic conditions were discussed theoretically.It indicated that the simultaneous reduction of alumina and silicon oxide by carbon at high temperature was beneficial to reduce $\mathrm{SiC}$ and $\mathrm{Al}_{4} \mathrm{C}_{3}$ in the products.It is feasible to prepare $\mathrm{Si}-\mathrm{Al}$ alloy by carbon reduction coal fly ash from thermodynamic analysis. The thermodynamic equilibrium components of carbon reduced coal fly ash were simulated by using Equilibrium Composition module, and it was considered that most of the reactions occurred during the reaction were the coupling of two or more reactions, rather than one by one.The preparation of $\mathrm{Si}-\mathrm{Al}$ alloy by carbon reduction coal fly ash is viable. In order to improve the yield of silicon and aluminum, the method of rapid heating can be used to avoid the formation of carbide, thereby reducing the content of $\mathrm{Al}_{2} \mathrm{O}$ and $\mathrm{SiO}$ in the equilibrium composition.

\section{Acknowledgments}

This work was financially supported by the Guizhou Provincial Science and Technology Foundation (No.[2014]7460),Solid Waste Recycling Laboratory of Coal Utilization(No.2011-278), the Liupanshui Normal University High-Level Talent Research Start Foundation (LPSSYKYJJ201 417), and Guizhou province ordinary college innovation team of mineral processing and comprehensive utilization of scientific and technological (No.[2015] 69).

\section{References}

[1]Ziyong Li,Chunhan Wu,Qingchun Yu,et al.J.Chin. Coal Soc.Vol.41(2016),p.769-775. In Chinese

[2] Y.L.Saraswathi,S.Das,D.P.Mondal.Mater.Sci.Eng A.Vol.3(2006),p.11-21.

[3]Xie Keqiang,Liu Ziliang,Ma Wenhui,et al.J.Kunming Uni.Sci.Techno.( Natural Science Edition). Vol.40(2015),p.1-7. In Chinese

[4]J.M. Lihrmann.J.Eur.Ceram.Soc.Vol.28(2008),p.633-642.

[5]Christoph Kemper,Efhtymios Balomenos,Dimitrios Panias. L. Met.(2014),p.789-794. 